Revista de la red interuniversitaria de estudios sobre las literaturas rioplatenses contemporáneas en Francia

$18 \mid 2018$

El río y la ciudad

\title{
Nadie sabe nada nunca
}

\section{Alejandra Costamagna}

URL: http://journals.openedition.org/lirico/5659

DOI: $10.4000 /$ lirico.5659

ISSN: 2262-8339

Editor

Réseau interuniversitaire d'étude des littératures contemporaines du Río de la Plata

\section{Referencia electrónica}

Alejandra Costamagna, « Nadie sabe nada nunca », Cuadernos LIRICO [En línea], 18 | 2018, Puesto en línea el 13 octubre 2018, consultado el 30 abril 2019. URL : http://journals.openedition.org/lirico/5659 ; DOI : 10.4000/lirico.5659

Este documento fue generado automáticamente el 30 abril 2019.

\section{(c) $(1) \Theta \Theta$}

Cuadernos LIRICO está distribuido bajo una Licencia Creative Commons Atribución-NoComercialSinDerivar 4.0 Internacional. 


\title{
Nadie sabe nada nunca
}

\author{
Alejandra Costamagna
}

Su vida cabe en una maleta, ahí está todo lo que necesita. Eso pensó hace unas horas, al bajar del Expreso Paraná. Acomodó las cosas, se miró al espejo sin verse y salió a recorrer la ciudad. Ahora deja que las piernas sigan una ruta indefinida. Cuando llega a la plaza se sienta en un banquito bajo un jacarandá. Quiere estar solo, fumar un cigarrillo y escuchar la melodía de las cigarras. Pero justo cuando saca el encendedor de su bolsillo, comienza a sonar una música festiva que anula todos los ruidos. Moreno mira a su alrededor: lo que ve es la sonrisa común de una veintena de jubilados. La musiquita esa, que sale de los parlantes emplazados en las esquinas del parque, los hace tan felices. Entonces deja el banco, acelera sus pasos y camina por la avenida principal hasta llegar al muelle. El olor a yuyo quemado que baja con el Paraná no parece inquietar a nadie. En la orilla del río hay una docena de patos negros con las plumas a mal traer. Se pasean en fila y parpan sincronizados, mezclando su canto con los murmullos de los ancianos. Moreno se fija que el muelle está lleno de viejos con expresión de alivio. Lo que los apacigua, piensa, es el puro hecho de respirar. Respirar ese aire que está muy lejos de ser puro. Igual que los patos, están aquí para matar las horas: eso alegra a Moreno. De golpe se siente en confianza con esta naturaleza. Deja que los pensamientos se disparen solos y se ve a sí mismo como un pato. Un pato feliz de su despiste en este comienzo de siglo, que se acomoda en el pasto y se dispone a encender un cigarrillo. Pero no alcanza a hacerlo cuando escucha el grito de un hombre, uno de los ancianos del lote, que le habla desde arriba:

-¡Pare! Aquí no se puede fumar.

-¿Cómo? -Moreno lo mira desde el suelo.

-Que no se puede fumar, le dicen.

-¿Dónde dice eso?

-Yo le estoy diciendo que está prohibido fumar -se impone el viejo con una voz aflautada.

-Pero si estamos en un lugar público. Y es un cigarrillo nada más.

-Es chistosito usted... -Moreno se siente cada vez más pequeño, sentado en el pasto, arrinconado. Un pato en cautiverio con las plumas estropeadas. Intenta levantarse, pero el desconocido lo detiene-. Momento -dice. $Y$ hace una señal de complicidad con la vista a un hombre sentado más atrás. Obedeciendo el llamado, el otro viejo se acerca y se cuadra 
frente a ellos. Moreno ve que lleva una libretita en la mano y una lapicera lista para disparar.

-Buenas tardes -saluda el recién llegado-. Samuel Calles.

-Martín Moreno.

-El señor iba a fumar aquí, ¿vio? -lo interrumpe el primero-. Y no sé si es tabaco lo que tiene.

-Ay, ay, ay -murmura Calles y escribe algo en la libretita.

-No sabía que estaba prohibido fumar, disculpen -se entrega Moreno.

-Nadie sabe nada nunca -recita Calles-. ¿De dónde venía ahora, del bar?

-Más o menos, o sea...

-Mejor no diga nada -ordena el viejo de la libreta y señala con el dedo índice la salida del muelle-. Circule, hágame el favor.

Moreno obedece, ya sin plumas, dislocado. Prácticamente por inercia llega a la estación de trenes. Se sienta en un banco de madera a esperar. No sabe qué es lo que espera, pero ahí está, sentado en su butaca, esperando al menos que las cosas mejoren. Ni siquiera atina a encender el cigarrillo censurado por los viejos. Escucha cómo las sirenas de bomberos afinan su melodía de las doce. Si fuera un pato, si volviera a serlo ahora mismo, caminaría con pasos ridículos por el cemento hasta alcanzar el pasto y luego el río. Se sumergiría en esas aguas espesas, que lo llevarían de vuelta a algún origen. Cualquier origen. Sabe que el río lo salvaría con solo acariciar sus plumas. Pero la imagen luego desaparece de su cabeza y queda solo, seco, con los pies en la tierra. 